\title{
Analysis of Articles on COVID-19: Is Scientific Productivity Parallel to Case Rates Across Countries?
}

\section{COVID-19 ile İlgili Makalelerin Analizi: Bilimsel Üretkenlik Ülkelerdeki Vaka Oranlarına Paralel Mi?}

\author{
Sibel YILMAZ FERHATOG̃LU'(İD), Nurgül YURTSEVEN'(IID) \\ ${ }^{1}$ Clinic of Anesthesiology and Reanimation, İstanbul Dr. Siyami Ersek Cardiac and Vascular Surgery Training and Research Hospital, \\ İstanbul, Turkey \\ Cite this article as: YIImaz Ferhatoğlu S, Yurtseven N. Analysis of articles on COVID-19: is scientific productivity parallel to case rates across countries? \\ FLORA 2020;25(4):490-8.
}

\begin{abstract}
Introduction: Scientific studies related to COVID-19 are pivotal for uncovering infection characteristics and exploring therapeutic procedures. Scientific data sharing is at the center of these efforts. The aim of this study is to investigate the activity and trends concerning COVID-19 since the beginning of 2020. We also investigated if there is a relationship between the number of cases-deaths and publication productivity of the countries.
\end{abstract}

Materials and Methods: The word "COVID-19" was searched in the Claritive Analytics ${ }^{\circledR}$, Web of Science (WOS) searching engine. All the articles indexed in Scientific Citation Index indexed journals were subjected to analysis.

Results: 16.618 articles were published in nine months. Authors from the People's Republic of China (PRC) and institutions in the United States of America (USA) had the highest publication rates. According to WOS categories, journals about "Medicine-General-Internal" were the most preferred journal category about COVID-19. There was no statistically significant correlation between publication metrics and pandemic statistics. The USA and PRC were the most productive two countries.

Conclusion: Publication productivity on COVID-19 may be the highest for any disease faced so far. Scientific productivity is higher in developed countries with fewer cases. We think scientists who have more comfortable working conditions and governmental support are scientifically more productive.

Key Words: COVID-19; SARS-COV2; Bibliometrics; Scientific productivity 


\title{
Öz
}

\section{Covid-19 ile İlgili Makalelerin Analizi: Bilimsel Üretkenlik Ülkelerdeki Vaka Oranlarına Paralel Mi?}

\author{
Sibel YILMAZ FERHATOG̃LU', Nurgül YURTSEVEN' ${ }^{1}$
}

\begin{abstract}
${ }^{1}$ İstanbul Dr. Siyami Ersek Gög̃üs Kalp ve Damar Cerrahisi Eg̃itim ve Araștırma Hastanesi, Anesteziyoloji ve Reanimasyon Kinig̃i İstanbul, Türkiye
\end{abstract}

Giriş: COVID-19 ile ilgili bilimsel çalışmalar, infeksiyon özelliklerini ortaya çıkarmak ve terapötik prosedürleri keşfetmek için çok önemlidir. Bilimsel veri paylaşımı, bu çabaların merkezinde yer almaktadır. Bu makale, 2020'nin başından beri COVID-19 ile ilgili faaliyetleri ve eğilimleri araştırmayı amaçlamaktadır. Biz aynı zamanda ülkelerin vaka-ölüm sayıları ile yayın üretkenliği arasında bir ilişki olup olmadığını da araştırdık.

Materyal ve Metod: COVID-19" kelimesi Claritive Analytics ${ }^{\circledR}$, Web of Science (WOS) arama motorunda arandı. 'Scientific Citation index' indeksli dergilerde indekslenen tüm makaleler analize tabi tutuldu.

Bulgular: Dokuz ayda 16.618 makale yayımlandı. Çin Halk Cumhuriyeti'nden (ÇHC) yazarlar ve Amerika Birleşik Devletleri'ndeki (ABD) enstitüler en yüksek yayın oranlarına sahip idi. WOS kategorilerine göre COVID-19 ile ilgili en çok tercih edilen dergi kategorisi 'Genel tıp - iç hastalıkları ve Genel Cerrahi' ile ilgili dergiler oldu. Yayın ölçümleri ile pandemi istatistikleri arasında istatistiksel olarak anlamlı bir ilişki yok idi. $A B D$ ve ÇHC en verimli iki ülke oldu.

Sonuç: COVID-19'daki bilimsel üretkenlik, günümüze kadar karşılaşılan hastalıklar içinde en yüksek olan olabilir. Daha az vakanın olduğu gelişmiş ülkelerde bilimsel verimlilik daha yüksektir. Daha rahat çalışma koşullarına ve devlet desteğine sahip bilim adamlarının bilimsel olarak daha üretken olduğunu düşünüyoruz.

Anahtar Kelimeler: COVID-19; SARS-COV2; Bibliyometri; Bilimsel üretkenlik

\section{INTRODUCTION}

In March 2020, the World Health Organization (WHO) announced the new COVID-19 pandemic, with the virus affecting more than 150.000 people in 154 nations as of March $15^{[1,2]}$. Over fifty-five million people have been infected with COVID-19, and this pandemic has consumed more than 1.3 million lives globally in about nine months ${ }^{[3]}$. Due to the rapidly increasing number of patients and severe clinical and public health management difficulties, national medical care systems have been oppressed. After the WHO announcement, global efforts have concentrated on resisting the rising pandemic. In order to overcome the pandemic, scientific data sharing and cooperation between nations have increased rapidly.

Data-sharing is the most critical determinant of the accelerated improvement and progress of science. Today, articles published on-line in international journals are one of the best and reliable ways of sharing information among scientists $^{[4]}$. This data-sharing via scientific publications would ease the delineation of risk factors, clinical characteristics, and treatment strategies for $\mathrm{CO}$ VID-19[5].

Bibliometric evaluation is the analytical assessment of a scientific publication, and it is an adequate method to estimate the impact of the scientific material in the academic world ${ }^{[6]}$. Besides, since the beginning of the pandemic, there has been an increase in the productivity and sharing of any scientific materials focusing on COVID-19 ${ }^{[7]}$.

The presented bibliometric study presents a panorama of scientific research that will assist in evidence-based information, comparisons, and visualizations of research produced in COVID-19. This investigation clarifies the topmost active authors, countries, journals, and institutions, and these studies become a guide for the researchers. 


\section{MATERIALS AND METHODS}

\section{Study Design}

We used, for obtaining the data of the presented study, the search engine of Clarivate Analytics ${ }^{\circledR}$, Web of Science (WOS) Web site, which is the leading database collecting citation and other academic impact information ${ }^{[8]}$ (http:// apps.webofknowledge.com), and PubMed ${ }^{\circledR}$ website (https://pubmed.ncbi.nlm.nih.gov/) which is an essential medical information resource for clinicians and researchers ${ }^{[9]}$.

We performed a search using the keyword "COVID-19" by selecting the "Topic" section on Nov 15, 2020. We sorted the articles in order of date, which is the current WOS default. After this process, we obtained the publication dates of the articles from the PubMed ${ }^{\circledR}$ database.

Inclusion criteria: Publications on the $\mathrm{CO}$ VID-19 topic published between Jan 1, 2020Nov 15, 2020 were included into study protocol.

Exclusion criteria: We filtered the results as Article (document type)", 2020 (year) as Science Citation Index Expanded (SCIE) (Web of Science Index). Other kind of publications were excluded.

Assessment of publication productivity among countries: As a research of the academic literature for an index, estimating the number of scientific publications and the number of cases affected by pathogen returned, there are no results. We assessed the countries' scientific productivity by applying a modified index named Scientific Productivity Index (SPI), calculated by the equation: the number of published articles $\mathrm{x}$ $100 /$ number of diagnosed cases. Thus, evaluation of the scientific productivity of COVID-19 of the countries became possible.

Evaluation of the collected data: We used the analysis function of the WOS Website for assessment. The publication rates, according to years, countries, and languages, were examined. Citation and h-index data were evaluated. The publication date of the articles was obtained from the PubMed ${ }^{\circledR}$ database. We also collected data about the COVID-19 pandemic from the website of the WHO (https://covid19.who.int/). All data were obtained and saved in Microsoft Excel ${ }^{\circledR}$ format on Nov 15, 2020.

\section{Statistical Analysis}

We applied the GNU operating system PSPP software program for statistical estimation. We practiced descriptive statistical techniques for estimating the data. Spearman's rank-order correlation analysis was applied to measure the strength of a monotonic relationship between paired data. The estimate of correlation was recognized as $0.26<r<0.49$ : low correlation; $0.50<r$ $<0.69$ : moderate correlation; $0.70<\mathrm{r}<0.89$ high correlation; $0.90<r<1.00$ : Very high correlation[10]. Statistical significance was taken as $\mathrm{p}<0.05$.

\section{RESULTS}

From the beginning of the pandemic up to Nov 15, 2020, 38195 publications focusing on COVID-19 have been published in the sources indexed in SCIE. The distribution of the publications according to document type, Article: 16618 (43.5\%), letter: 7951 (20.7\%), editorial material: 7371 (19.3\%), review: 4175 (10.8\%), new items: 985 (2.6\%), and others: 1365 (3.5\%). We conducted the study with 16618 articles after applying inclusion and exclusion criteria specified in the presented study's materials methods section.

The five most productive countries were the United States of America (USA), the Peoples' Republic of China (PRC), Italy, England, and Germany. Publication, citation metrics, an h-index of the most productive ten countries were shown in Table 1. Although the USA is the most productive country in article number, PRC is the first country in citation number and h-index measurement.

The most active organizations/institutions producing scientific material about the COVID-19 topic are Harvard University from the USA, the Huazhong University of Science Technology from the PRC, and the University of London from England. Also, five of the ten most productive institutions were from the USA (Table 1). Unlike organizations/institutions, authors from the PRC were the most active on the COVID-19 topic. Wang J. from Tongde Hospital, PRC, has produced one hundred nineteen articles on COVID-19; 
Table 1. Top ten productive countries, organizations-institutions, authors and journals and most preferred web of science category

\begin{tabular}{|c|c|c|c|}
\hline Country & Article n (\%) & Citation $\mathrm{n}(\%)$, Mean \pm SD (min-max) & h-index \\
\hline USA & $5004(30.1)$ & $16852(14.6), 8.3 \pm 39.7(0-1000)$ & 90 \\
\hline $\mathrm{PRC}^{*}$ & $3342(20.1)$ & $20486(16.6), 19.2 \pm 121.5(0-4441)$ & 117 \\
\hline İtaly & $1919(11.5)$ & $9183(7.4), 8.2 \pm 35.7(0-716)$ & 55 \\
\hline England & $1568(9.4)$ & $10156(8.2), 9.8 \pm 48.6(0-1000)$ & 56 \\
\hline Canada & $757(4.5)$ & $5055(4.1), 20.7 \pm 37.6(0-445)$ & 38 \\
\hline Germany & $932(5.6)$ & $7032(5.7), 10.3 \pm 49.8(0-753)$ & 43 \\
\hline Australia & $702(4.2)$ & $4150(3.4), 6.9 \pm 39.9(0-438)$ & 31 \\
\hline France & $810(4.8)$ & $6212(5), 10.9 \pm 54.8(0-1162)$ & 41 \\
\hline Spain & $826(4.9)$ & $4979(4), 7.6 \pm 36.4(0-632)$ & 35 \\
\hline India & $827(4.9)$ & $1937(1.6), 3.5 \pm 12.0(0-194)$ & 24 \\
\hline \multicolumn{4}{|l|}{ Wos category } \\
\hline Medicine general internal & $1582(9.5)$ & 14265 (11.5), $17.9 \pm 161.0(0-4441)$ & 68 \\
\hline Public environmental occupational health & $1489(8.9)$ & $4266(3.5), 4.3 \pm 23.4(0-612)$ & 32 \\
\hline Infectious diseases & $1211(7.2)$ & $8716(7.1), 12.2 \pm 54.5(0-1162)$ & 57 \\
\hline Enviromental sciences & $918(5.5)$ & $1882(5.5), 5.4 \pm 23.8(0-612)$ & 32 \\
\hline Surgery & $755(4.5)$ & 1964 (1.5), $5.2 \pm 14.6(0-229)$ & 30 \\
\hline Multidisciplinary sciences & $730(4.4)$ & $5449(4.4), 13.5 \pm 55.4(0-753)$ & 53 \\
\hline Immunology & $688(4.1)$ & 4197 (3.4), $9.2 \pm 32.8(0-583)$ & 41 \\
\hline Health care sciences services & $648(3.9)$ & $1152(0.9), 2.5 \pm 10.5(0-169)$ & 18 \\
\hline Medicine research experimental & $629(3.7)$ & $4281(3.5), 9.1 \pm 43.3(0-506)$ & 37 \\
\hline Pharmacology pharmacy & $629(3.7)$ & $3694(3), 9.2 \pm 58.6(0-1162)$ & 32 \\
\hline \multicolumn{4}{|l|}{ Organizations - Instutitions } \\
\hline $\begin{array}{l}\text { Huazhong University of } \\
\text { Science Technology (PRC) }\end{array}$ & $554(3.3)$ & $11212(9.1), 32.8 \pm 217.8(0-4481)$ & 61 \\
\hline Harvard University (USA) & $628(3.7)$ & 5149 (4.2), $9.4 \pm 41.0(0-472)$ & 40 \\
\hline University of London (United Kingdom) & $475(2.8)$ & $5194(4.2), 9.8 \pm 46.4(0-457)$ & 35 \\
\hline Wuhan University (PRC) & $342(2.0)$ & $5488(4.4), 22.2 \pm 69.3(0-592)$ & 43 \\
\hline University of California System (USA) & $455(2.7)$ & 4589 (3.7), $9.2 \pm 34.8(0-318)$ & 35 \\
\hline $\begin{array}{l}\text { Inst. Nat. De La Sante Et De La Recherche Med. } \\
\text { Inserm (France) }\end{array}$ & $286(1.7)$ & $3680(3), 14.8 \pm 81.3(0-1169)$ & 26 \\
\hline $\begin{array}{l}\text { Assistance Publique Hopitaux Paris APHP } \\
\text { (France) }\end{array}$ & $264(1.5)$ & $2523(2), 10.3 \pm 41.3(0-454)$ & 23 \\
\hline University of Texas System (USA) & $237(1.4)$ & $1555(1.3), 5.6 \pm 16.2(0-102)$ & 23 \\
\hline Harvard Medical School (USA) & $393(2.3)$ & $4071(3.3), 12.0 \pm 42.8(0-472)$ & 34 \\
\hline University of Toronto (USA) & $235(1.4)$ & $1948(1.6), 7.4 \pm 46.5(0-444)$ & 21 \\
\hline \multicolumn{4}{|l|}{ Authors } \\
\hline Wang J (PRC/Tongde Hospital) & $119(0.7)$ & 3150 (2.5), $28.2 \pm 109.4(0-1010)$ & 23 \\
\hline $\begin{array}{l}\text { Liu Y (England/London School of Hygiene \& } \\
\text { Tropical Medicine) }\end{array}$ & $100(0.6)$ & $9220(7.5), 108.7 \pm 581.5(0-4481)$ & 25 \\
\hline Wang Y (PRC/Wuhan Univ Sci \& Technol) & $114(0.6)$ & $3246(2.6), 32.7 \pm 118.3(0-1010)$ & 23 \\
\hline
\end{tabular}


Table 1. Top ten productive countries, organizations-institutions, authors and journals and most preferred web of science category (continue)

\begin{tabular}{|c|c|c|c|}
\hline & Article n (\%) & Citation $\mathrm{n}(\%)$, Mean \pm SD (min-max) & h-index \\
\hline $\begin{array}{l}\text { Liu J (PRC/Cent South Univ, Xiangya Hosp, Dept } \\
\text { Radiol, Changsha) }\end{array}$ & $92(0.5)$ & $5455(4.4), 62.3 \pm 464.7(0-4481)$ & 19 \\
\hline Li L (PRC/Fujian Prov Hospital) & $77(0.4)$ & $5566(4.5), 79.1 \pm 512.8(0-4481)$ & 17 \\
\hline Li Y (PRC/Henan Univ, Key Lab) & $89(0.5)$ & $1137(0.9), 11.9 \pm 37.7(0-247)$ & 13 \\
\hline $\begin{array}{l}\text { Chen Y (PRC/Zhejiang Prov Ctr Dis Control \& } \\
\text { Prevent, Hangzhou) }\end{array}$ & $79(0.4)$ & $1463(1.2), 12.3 \pm 44.9(0-237)$ & 18 \\
\hline Wang L (PRC/Huazhong Univ Sci \& Technol) & $82(0.5)$ & $1916(1.5), 24.2 \pm 59.7(0-271)$ & 20 \\
\hline $\begin{array}{l}\text { Zhang Y (PRC/Chinese Acad Med Sci, Peking } \\
\text { Union Med Coll) }\end{array}$ & $104(0.6)$ & $3067(2.5), 41.4 \pm 381.8(0-1010)$ & 18 \\
\hline Chen J (PRC/Huazhong Univ Sci \& Technol) & $78(0.4)$ & $1935(1.6), 27.2 \pm 87.0(0-621)$ & 20 \\
\hline \multicolumn{4}{|l|}{ Journals } \\
\hline $\begin{array}{l}\text { Int. J. of Environmental Research and Public } \\
\text { Health** }\end{array}$ & $362(2.1)$ & $1078(0.9), 4.5 \pm 33.6(0-624)$ & 14 \\
\hline Journal of Medical Virology & $265(1.6)$ & $2465(1.8), 12.0 \pm 34.0(0-293)$ & 28 \\
\hline Plos one & $260(1.5)$ & $402(0.3), 1.8 \pm 8.3(0-108)$ & 10 \\
\hline International Journal of Infectious Diseases & $198(1.2)$ & $1702(1.4), 10.0 \pm 29.6(0-342)$ & 22 \\
\hline Science of the Total Environment & $158(0.9)$ & $757(0.6), 13.9 \pm 21.2(0-99)$ & 26 \\
\hline Journal of Biomolecular Structure Dynamics & $157(0.9)$ & $231(0.2), 5.5 \pm 14.3(0-80)$ & 14 \\
\hline Journal of Chemical Education & $155(0.9)$ & $6(<0.1), 0.1 \pm 0.5(0-5)$ & 2 \\
\hline Sustainability & $126(0.7)$ & $97(<0.1), 0.9 \pm 2.9(0-20)$ & 6 \\
\hline Frontiers in Public Health & $121(0.7)$ & $230(0.2), 1.9 \pm 11.6(0-130)$ & 6 \\
\hline Journal of Medical Internet Research & $121(0.7)$ & $194(0.1), 2.3 \pm 4.8(0-36)$ & 10 \\
\hline
\end{tabular}

he has 3150 (2.5\%) citations with an h-index of twenty-three (Table 1).

The articles have been cited a total of 115424 times (excluding self-citations). Citation numbers by country are shown in Table 1. According to WOS categories, journals about "Medicine-General-Internal" and "Public Environmental Occupational Health" are the most preferred journals about the COVID-19 (Table 1).

Statistics on COVID-19 pandemic: The USA, India, and Brazil are the three leading countries in terms of the number of cases. However, considering the number of deaths per million, Spain, Brazil and England were the first three countries (Table 2).

Correlation among publication- $\mathrm{CO}$ VID-19 pandemic statistics: There was a posi- tive correlation between publication numbers and citation numbers $(r=0.98, p<0.001)$, but there was no statistically significant correlation between publication metrics and pandemic statistics (Figure 1) (Table 3).

Publication productivity of the countries according to the number of cases: The SPI scores of the most productive ten countries were; Taiwan: 32.9; Vietnam: 6.6; New Zealand: 4.7; PRC: 4.0; Australia: 2.6; Thailand: 2.0; Tanzania: 1.9; South Korea: 1.2; Singapore: 0.4; Cyprus: 0.4 , respectively.

\section{DISCUSSION}

COVID-19 has indisputably become the central issue of scientific organizations worldwide from the beginning of 2020. Sixteen thousand six hundred eighteen published SCIE indexed ar- 


\begin{tabular}{|c|c|c|c|c|c|}
\hline Country & Case $(n)$ & Cases per million $(n)$ & Total recovery $(n)$ & Death $(\mathrm{n})$ & Deaths per million $(n)$ \\
\hline USA* & 10933918 & 33032 & - & 244411 & 754.4 \\
\hline Brazil & 5863093 & 27583 & 5360000 & 165798 & 789.8 \\
\hline Russia & 1971013 & 13506 & 1500000 & 33931 & 232.8 \\
\hline England & 1390685 & 20485 & - & 52147 & 787.7 \\
\hline Spain & 1458591 & 31196 & 150000 & 40769 & 885.5 \\
\hline Italy & 1205881 & 19944 & 458000 & 45733 & 770.5 \\
\hline India & 8874290 & 6430 & 8340000 & 130519 & 95.8 \\
\hline France & 1954562 & 29944 & 143000 & 44719 & 681.3 \\
\hline Colombia & 1198746 & 23558 & 1120000 & 34031 & 682.9 \\
\hline Argentina & 1310491 & 28995 & 1150000 & 35436 & 803.4 \\
\hline $\mathrm{PRC}^{*} \dagger$ & 86369 & 60 & 81411 & 4639 & 3.39 \\
\hline
\end{tabular}

*USA: United States of America, PRC: The peoples republic of China.

†PRC is $62^{\text {nd }}$ according to the number of cases.

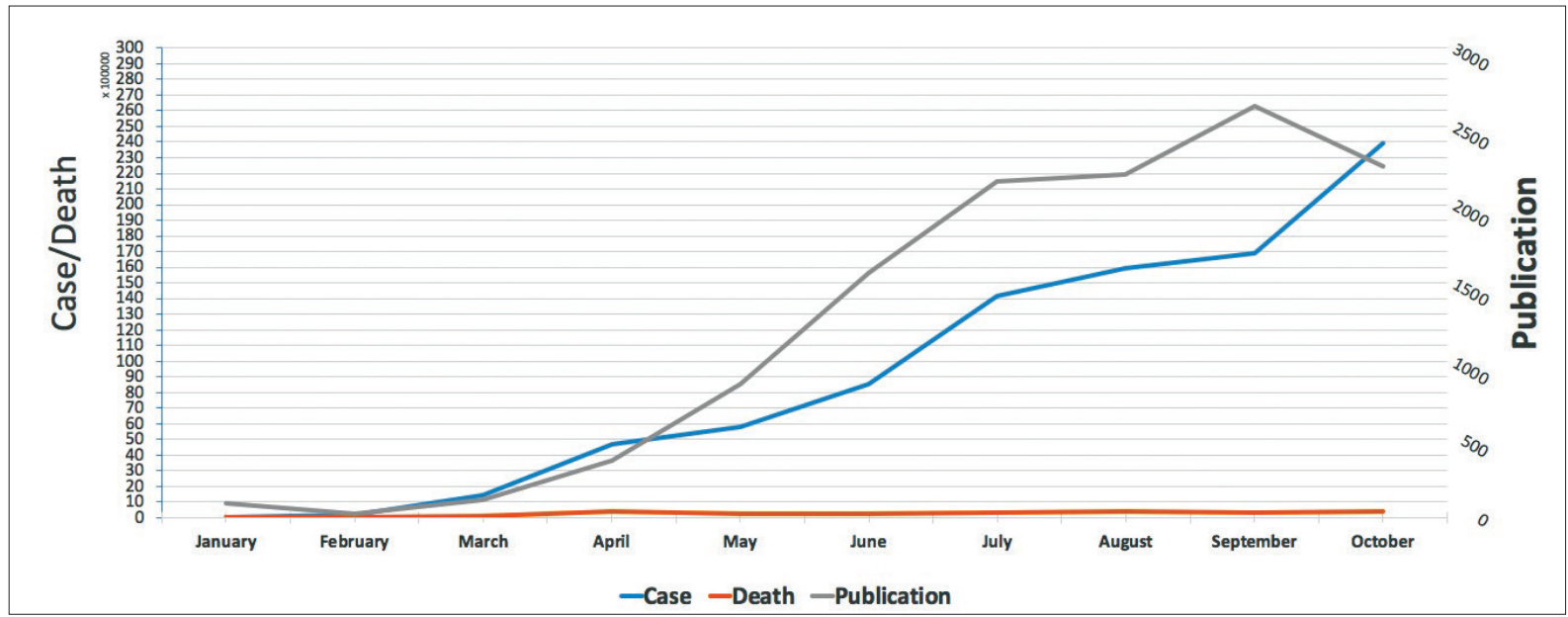

Figure 1. Demonstration of the monthly case, death, and publication statistics.

ticles, just in nine months, are the most significant proof of this focus. The scientific literature has reacted as promptly as the development of the pandemic. It has exponentially increased the alertness of the scientist and the public on the $92^{\text {nd }}$ day of the pandemic announcement by WHO, three thousand two hundred publications. On the $113^{\text {th }}$ day, 6831 articles declared about COVID-19 (including all index) ${ }^{[11]}$. These publication productivities mean an extraordinary daily publication number of 34.8 (on $92^{\text {nd }}$ day) and 58.9 (on $113^{\text {th }}$ day) articles. Although we only considered the SCIE indexed articles in the presented study, we see this extraordinary scientific productivity is still increasing with 63.9 articles per day. Although these publication rates are considerably high-rise in such a limited-time for any condition, we consider that there are several unindexed publications on the WOS due to various causes (published as ahead of print or preprint and waiting to be printed in a regular issue of the journal, some scientific journals have an embargo time, some journals are not indexed on the WOS database).

Since the PRC is the birthplace of the $\mathrm{CO}$ VID-19 pandemic ${ }^{[12]}$, Chinese authors produced most of the COVID-19-related articles as an ex- 
Table 3. Assessment of the relationship between COVID-19 and publication statistics

\begin{tabular}{|c|c|c|c|c|c|c|c|c|}
\hline & & $\begin{array}{c}\text { Number of } \\
\text { Case }\end{array}$ & $\begin{array}{l}\text { Number } \\
\text { of death }\end{array}$ & $\begin{array}{c}\text { Total } \\
\text { recovery } \dagger\end{array}$ & $\begin{array}{l}\text { Case per } \\
\text { million }\end{array}$ & Population & $\begin{array}{c}\text { Number of } \\
\text { articles }\end{array}$ & $\begin{array}{c}\text { Number of } \\
\text { citations }\end{array}$ \\
\hline \multirow[t]{2}{*}{ Number of case } & $r$ & 1.000 & & & & & & \\
\hline & $p$ & - & & & & & & \\
\hline \multirow[t]{2}{*}{ Number of death } & $r$ & 0.8756 & 1.000 & & & & & \\
\hline & $p$ & $\mathrm{p}<0.001^{* * *}$ & - & & & & & \\
\hline \multirow[t]{2}{*}{ Total recovery } & $r$ & 0.1219 & 0.1969 & 1.000 & & & & \\
\hline & $p$ & $p<0.001^{\star * *}$ & $0.0173^{*}$ & - & & & & \\
\hline \multirow[t]{2}{*}{ Case per million } & $r$ & 0.2948 & 0.4185 & 0.3312 & 1.000 & & & \\
\hline & $p$ & 0.136 & 0.06 & 0.291 & - & & & \\
\hline \multirow[t]{2}{*}{ Population } & r & -0.0785 & -0.1682 & -0.1377 & -0.4143 & 1.000 & & \\
\hline & $\mathrm{p}$ & 0.819 & 0.563 & 0.736 & $0.015^{*}$ & - & & \\
\hline \multirow[t]{2}{*}{ Number of articles } & $r$ & 0.5969 & 0.3585 & 0.3841 & -0.5254 & 0.5542 & 1.000 & \\
\hline & $\mathrm{p}$ & 0.376 & 0.214 & 0.43 & 0.74 & 0.969 & - & \\
\hline \multirow[t]{2}{*}{ Number of citations } & $r$ & 0.1917 & 0.2651 & 0.0603 & -0.5839 & 0.5392 & 0.9826 & 1.000 \\
\hline & $p$ & 0.721 & 0.685 & 0.886 & 0.434 & 0.059 & $\mathrm{p}<0.001^{* * *}$ & - \\
\hline $\begin{array}{l}\text { r: Spearman's rho. } \\
{ }^{*} p<0.05 \\
{ }^{* *} p<0.01 \\
{ }^{* * *} p<0.001 \\
\dagger \text { †ue to the lack of dat } \\
\text { from the analysis of the }\end{array}$ & & $r$ of patien & verino & ies on the $d$ & & $\mathrm{dH}$ & 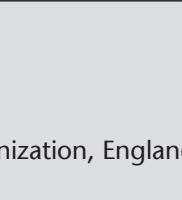 & . \\
\hline
\end{tabular}

pected event. Although Argentina and Colombia had $4.6 \%$ of all COVID-19-diagnosed cases, they have only produced 159 (0.9\%) articles. Although approximately $1 \%$ of all COVID-19-diagnosed cases are seen in Chile, Chile has had no contribution to the scientific literature. The reason for this low scientific productivity inconsistent with the high number of cases may be the political strain on the healthcare systems and medical professionals in these countries. Like Chile, Argentina, and Columbia, Russia and Brazil are two other under-productive countries. Although 3.6\% of the cases worldwide are in Russia, the rate of scientific articles remained at $0.7 \%$, and $10.0 \%$ of all COVID-19 diagnosed patients were in Brazil; Brazil was not in the top ten nations in scientific productivity. However, in 2018, Russia and Brazil ranked $14^{\text {th }}$ and $20^{\text {th }}$ out of 224 countries in the annual scientific study production, with close to 40000 studies $^{[13]}$. These findings show that the lack of scientific productivity is not due to a lack of scientific experience or qualified academic organizations but rather due to the overstrained medical institutions and medical professionals fa- cing the rapidly spreading COVID-19 pandemic. We assume scientists consider healthcare as the main priority over producing scientific studies. Unlike other countries, we believe that one of the reasons for the high scientific productivity on COVID-19 of PRC is to have more than 3.6 million licensed medical doctors ${ }^{[14]}$.

As a surprising finding of our work, we found that the most productive countries related to COVID-19 case numbers were Taiwan and Vietnam. These rankings about scientific productivity on COVID-19 create a perception that these countries are already scientifically productive. However, in 2018, Taiwan and Vietnam ranked $23^{\text {th }}, 59^{\text {th }}$ out of 224 countries in the annual scientific study production report ${ }^{[13]}$. When considering the number of COVID-19 cases diagnosed in Taiwan, Vietnam (617 and 1304, respectively), low number of cases may be due to inability or incapacity in diagnosis. We believe defects in diagnosing COVID-19 cases or problems in reporting cases negatively affected the SPI's reliability in the presented study. 
Various high-impact factor scientific journals have published specific issues focusing on the COVID-19 pandemic, providing top-priority and fast-tracking and free-access. Although the publication rate is high, there are only a few high-quality studies published on this topic. The majority of the presented studies are narrative opinions, guidelines, case reports, or series, rather than evidence-based publications like systematic reviews, meta-analysis, and multicenter studies on a more significant number of these cases. We assure, as the medical professionals/scientists get more information about the COVID-19, more powerful, evidence-based studies would be announced. This remarkable scientific productivity on COVID-19 in such a short period is due to numerous reasons: First, this novel pathogen has influenced and alerted humanity. Second, the social-life lockdown has provided more time for scientists to publish on COVID-19, and third, most scientific journals have become more inviting on COVID-19 studies.

Limitations of the study: The presented research is the first study focusing on COVID-19 related articles printed in SCIE indexed journals. The presented research's primary weakness is the lack of investigating other well-known databases like PubMed, Scopus, or Google Scholar, apart from WOS. However, WOS is the most trustworthy information source about publications published in SCIE indexed journals. Including only articles published in SCIE indexed journals can be seen as another limitation of our study; however, to standardize the quality of scientific publications, we only studied SCIE indexed articles.

\section{CONCLUSION}

We recognized a notable development in the number of articles about COVID-19 since the outbreak began. This high publication speed may be the highest for any disease faced so far. As expected, the USA and PRC are the upmost countries in publication productivity. Scientists who have more comfortable working conditions are scientifically more productive. Studies focusing on therapeutic methods may assist in discovering novel treatment modalities. Raising these interests is necessary to increase the research output on this novel pathogen.

\section{ETHICS COMMITTEE APPROVAL}

Formal approval is not required for this type of study.

\section{CONFLICT of INTEREST}

The authors declare that they have no conflict of interest.

\section{AUTHORSHIP CONTRIBUTIONS}

Concept and Design: SYF

Data Collection or Processing: SYF

Analysis/ Interpretation: SYF

Literature Search: SYF

Writing: NY

Final Approval: NY

\section{REFERENCES}

1. Sohrabi C, Alsafi Z, O'Neill N, Khan M, Kerwan A, Al-Jabir $A$, et al. World Health Organization declares global emergency: a review of the 2019 novel coronavirus (COVID-19). Int J Surg 2020;76:71-6.

2. Rothan HA, Byrareddy SN. The epidemiology and pathogenesis of coronavirus disease (COVID-19) outbreak. J Autoimmun 2020;102433.

3. The World Health Organization (WHO). Coronavirus disease (COVID-2019) situation reports. WHO. Available from: https://www.who.int/emergencies/diseases/novel-coronavirus-2019/situation-reports

4. Mello MM, Francer JK, Wilenzick M, Teden P, Bierer BE, Barnes M. Preparing for responsible sharing of clinical trial data. N Engl J Med 2013;369:1651-8.

5. Guan WJ, Ni ZY, Hu Y, Liang WH, Qu CQ, He JX, et al. Clinical characteristics of coronavirus disease 2019 in China. N Engl J Med 2020;382:1708-20.

6. Ferhatoglu SY, Yapici N. A Bibliometric analysis of the articles focusing on the subject of brain death published in scientific citation index-expanded indexed journals: analysis of 3487 articles published between 1995-2019. Transplant Proc 2020;52:706-11.

7. Chahrour M, Assi S, Bejjani M, Nasrallah AA, Salhab $H$, Fares $M$, et al. A bibliometric analysis of COVID-19 research activity: a call for increased output. Cureus 2020;12:e7357.

8. Li L, Ma X, Pandey S, Deng X, Chen S, Cui D, et al. The most-cited works in severe traumatic brain injury: a bibliometric analysis of the 100 most-cited articles. World Neurosurg 2018;113:82-7.

9. Falagas ME, Pitsouni El, Malietzis GA, Pappas G. Comparison of PubMed, Scopus, Web of Science, and Google Scholar: strengths and weaknesses. FASEB J 2008;22:338-42. 
10. Ramsey PH. Critical values for Spearman's rank order correlation. J Educ Stat Fall 1989;14:245-53.

11. Kambhampati SBS, Vaishya R, Vaish A. Unprecedented surge in publications related to COVID-19 in the first three months of pandemic: A bibliometric analytic report. J Clin Orthop Trauma 2020;11:304-6.

12. Chen $Y$, Zhao $M, W u Y$, Zang S. Epidemiological analysis of the early 38 fatalities in Hubei, China, of the coronavirus disease 2019. J Glob Health 2020;10:011004.

13. Scimago Journal \& Country Rank. Research Output by Country 2019. Available from: https://www.scimagojr. com/countryrank.php? area $=2700$ \&year $=2019$
14. Statisca. Number of Licensed Doctors in China from 2008 to 2018. Available from: https://www.statista.com/statistics/279326/number-of-licensed-doctors-in-china/.

\section{Address for Correspondence/Yazıșma Adresi}

Uzm. Dr. Sibel YILMAZ FERHATOĞLU

İstanbul Dr. Siyami Ersek Göğüs Kalp ve Damar Cerrahisi Eğitim ve Araștırma Hastanesi Anesteziyoloji ve Reanimasyon Kiniği İstanbul-Türkiye

E-mail: sibelyf@yandex.com 